\title{
The Basics of Hydrogen Uptake in Iron and Steel
}

\author{
Mathias Truschner, Anton Trautmann, and Gregor Mori \\ Chair of General and Analytical Chemistry, Montanuniversität Leoben, Leoben, Austria
}

Received July 28, 2021; accepted August 11, 2021; published online September 10, 2021

\begin{abstract}
Armco iron and L80 steel (according to API 5CT) were charged under various conditions due to often not knowing the exact amount of hydrogen absorbed during operation and laboratory charging. These two materials were charged in sodium chloride $(\mathrm{NaCl})$, sulfuric acid $\left(\mathrm{H}_{2} \mathrm{SO}_{4}\right)$, both with and without addition of thiourea $\left(\mathrm{CH}_{4} \mathrm{~N}_{2} \mathrm{~S}\right.$ ), and in $\mathrm{H}_{2} \mathrm{~S}$ (NACE TM0177) at open circuit potential.

Additionally, cathodic charging was done in sodium chloride and sulfuric acid, both with thiourea added at a current density of $1 \mathrm{~mA} / \mathrm{cm}^{2}$. The charging time was between 2 and $336 \mathrm{~h}$ for both methods. Prior to the charging, the specimens were cleaned in acetone and the bulk hydrogen content of the two materials was determined. After charging, the specimens were ground with a silicone carbide paper and the hydrogen content was measured with a thermal conductivity cell after hot extraction at $950^{\circ} \mathrm{C}$.

Most of the immersion tests at open circuit potential resulted in hydrogen concentrations of up to $1 \mathrm{wt}$. ppm, while the cathodic charging led to values of up to $4 \mathrm{wt}$. ppm. In addition, the NACE TM0177 test provided the highest hydrogen concentrations and was the only test to show higher hydrogen concentrations for Armco iron than for L80 steel.
\end{abstract}

Keywords: Hydrogen embrittlement, Carbon steel, Cathodic charging, Immersion test

Die Grundlagen der Wasserstoffaufnahme in Eisen und Stahl

Zusammenfassung: Armco-Eisen und L80-Stahl (nach API $5 \mathrm{CT}$ ) wurden unter verschiedenen Bedingungen mit Wasserstoff beladen, da die Wasserstoffmenge, die während des Betriebs und im Laboratorium aufgenommen wird, oft nur unzureichend bekannt ist. Diese beiden Materialien wurden in Natriumchlorid-Lösungen ( $\mathrm{NaCl}$ ), Schwefelsäure

M. Truschner ( $\square)$

Chair of General and Analytical Chemistry,

Montanuniversität Leoben,

Franz-Josef-Straße 18,

8700 Leoben, Austria

mathias.truschner@unileoben.ac.at
$\left(\mathrm{H}_{2} \mathrm{SO}_{4}\right)$, sowohl mit als auch ohne Zusatz von Thioharnstoff $\left(\mathrm{CH}_{4} \mathrm{~N}_{2} \mathrm{~S}\right)$, und in $\mathrm{H}_{2} \mathrm{~S}$-gesättigter $\mathrm{NaCl} / \mathrm{CH}_{3} \mathrm{COOH}$-Lösung (NACE TM0177) bei Ruhepotential beladen.

Zusätzlich wurde die kathodische Beladung bei einer Stromdichte von $1 \mathrm{~mA} / \mathrm{cm}^{2}$ in $\mathrm{NaCl}$ - und $\mathrm{H}_{2} \mathrm{SO}_{4}$-Lösungen durchgeführt, beide mit Thioharnstoff Zusatz. Die Beladungsdauer lag bei beiden Verfahren zwischen 2 und $336 \mathrm{~h}$. Vor der Beladung wurden die Proben in Aceton gereinigt und ihr Grundwasserstoffgehalt bestimmt. Nach dem Beladen wurden die Proben mit Siliziumkarbidpapier geschliffen und der Wasserstoffgehalt mit einer Wärmeleitfähigkeitsmesszelle nach Trägergasheißextraktion bei $950^{\circ} \mathrm{C}$ gemessen.

Die meisten Auslagerungsversuche bei Ruhepotential führten zu Wasserstoffkonzentrationen von bis zu $1 \mathrm{Gew}$.-ppm, während die kathodische Beladung zu Werten von bis zu 4 Gew.-ppm führte. Darüber hinaus lieferte der Test nach NACE TM0177 die höchsten Wasserstoffkonzentrationen und war der einzige Test, der für das Armco-Eisen höhere Wasserstoffkonzentrationen als für den L80-Stahl zeigte.

Schlüsselwörter: Wasserstoffversprödung, Kohlenstoffstähle, Kathodische Wasserstoffbeladung, Auslagerung

\section{Introduction}

As early as 1874, Johnson first found a connection between the embrittlement of steel and the absorption of hydrogen after immersion in acids [1]. Since then, researchers have been trying to explain the mechanism of hydrogen embrittlement, while the absorption of hydrogen is often overlooked.

The aim of this contribution is to explain the mechanisms of hydrogen uptake and to determine the hydrogen uptake of Armco iron and L80 steel under various conditions.

In principle, atomic hydrogen is required for a hydrogen uptake, which is present in adsorbed form at the interface between the medium and the solid and is subsequently absorbed into the metal. Thus there are three basic possibilities for the absorption of hydrogen. 


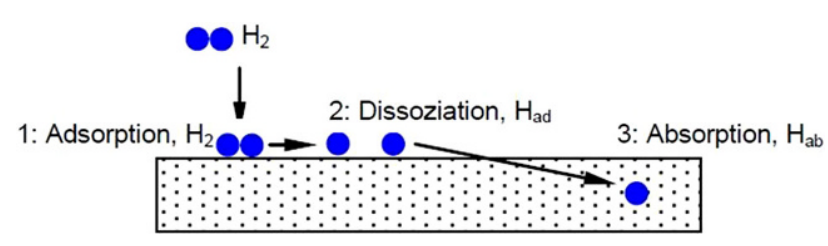

Fig. 1: Mechanism of absorption of hydrogen via the gas phase [2]

First, absorption can take place under pressure and is therefore referred to as pressurized hydrogen charging. In order to overcome the required enthalpy of dissociation, it is necessary to carry out pressurized hydrogen charging tests at increased hydrogen partial pressure and/or increased temperatures. A possibility of hydrogen absorption, which is also possible at low temperatures and partial pressures, is shown in Fig. 1. In the first step, physical adsorption, hydrogen is adsorbed in molecular form via Vander-Waals forces on the surface. In the second sub-step, chemical adsorption, the hydrogen molecule dissociates in order to assume the energetically more favorable state at sliding stages or surface defects. The atomically present hydrogen can then be absorbed by the material.

The hydrogen partial pressure and the temperature, which are shown as resistance limits in Nelson curves, are the main influencing factors of hydrogen absorption under pressurized hydrogen charging [3].

The second possibility for hydrogen uptake are corrosion reactions, which are investigated in the form of immersion tests and are often referred to as electrolytic hydrogen charging (Fig. 2).

Hydrogen is produced by the so-called Volmer reaction in aqueous solutions according to the following equation $[2,4]$ :

$$
H^{+}+e^{-} \leftrightarrow H_{a d}
$$

Depending on the reaction conditions, the hydrogen atom adsorbed on the metal surface is either absorbed (2) or desorbed according to the Tafel reaction (3):

$$
\begin{aligned}
H_{a d} & \leftrightarrow H_{a b} \\
2 H_{a d} & \leftrightarrow(H 2)_{a d}
\end{aligned}
$$

Another possibility of desorption is the Heyrovsky mechanism, which also leads to a recombination to the $\mathrm{H}_{2}$ molecule according to the following equation:

$$
H_{a d}+H^{+}+e^{-} \leftrightarrow(H 2)_{a d}
$$

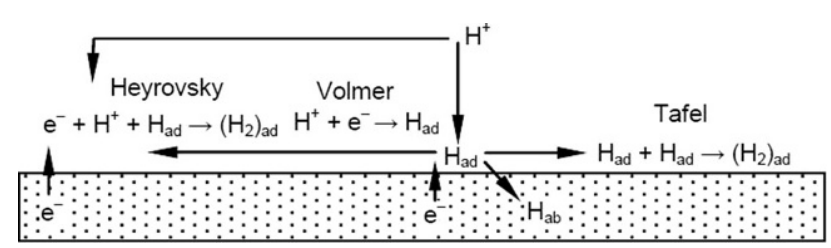

Fig. 2: Reactions during the absorption of hydrogen in acidic electrolytes [2]
Due to the formation of local corrosion elements, a cathodic hydrogen deposition takes place at different locations on the sample during the corrosion process.

The absorption of hydrogen during immersion depends primarily on the corrosion attack and the formation of the top layer. The more the material is attacked, the more hydrogen is formed and can be absorbed into the material.

The third possibility of hydrogen uptake is due to an applied potential and is known as cathodic hydrogen charging [5-8]. In contrast to hydrogen charging by corrosion, cathodic hydrogen charging can also be carried out in a neutral medium. Atomic hydrogen is formed by the chemical reduction of water at the cathodically polarized electrode [6]:

$$
\mathrm{H} 2 \mathrm{O}+\mathrm{e}^{-} \leftrightarrow \mathrm{H}_{\mathrm{ad}}+\mathrm{OH}^{-}
$$

For cathodic hydrogen charging, the charge current density is the main influencing factor. In addition, there is a difference in the use of neutral or acidic solutions, since acidic solutions lead to absorption through corrosion [9].

Other influencing factors for the absorption of hydrogen are the use of hydrogen recombination poisons and the structure of the materials that are charged. The most commonly used hydrogen recombination poisons (hydrogen sulfide, arsenic oxide, thiourea and ammonium thiocyanate) inhibit the recombination reaction of atomic hydrogen and thus increase the uptake of hydrogen into the material [10-12].

\section{Experimental Procedure}

\subsection{Materials Investigated}

Armco iron and L80 steel (API ${ }^{(1)} 5 \mathrm{CT}$ L80 Type 1) with a sample geometry of $30 \times 6 \times 6 \mathrm{~mm}$ were used as test materials. Armco iron was subjected to a one-hour diffusion annealing in a stainless steel foil-to prevent scaling-prior to sample fabrication and subsequently cooled in air. The raw material for L80 steel is a commercially available seamless tube. The L80 specification stands for a minimum yield strength of $80 \mathrm{ksi}$ (equivalent to $552 \mathrm{MPa}$ ). The chemical compositions of the two investigated materials are shown in Table 1.

Fig. 3 shows the microstructures of the examined materials. Armco iron shows large grains of ferrite, with a grain size in the range of $100 \mu \mathrm{m}$, without the presence of a second phase or other precipitates. The microstructure of L80 steel is much finer than that of Armco iron and has therefore a larger number of traps. The grain size of the former austenite grains ranges from 20 to $40 \mu \mathrm{m}$. The microstructure of $L 80$ steel consists of tempered martensite.

The mechanical properties of the investigated materials are listed in Table 2.

\footnotetext{
1 American Petroleum Institute (API), 1220 L St., N.W., Washington, DC 20005-4070.
} 


\begin{tabular}{|c|c|c|c|c|c|c|}
\hline Material & $\begin{array}{l}\text { C } \\
\text { [wt.-\%] }\end{array}$ & $\begin{array}{l}\mathrm{Mn} \\
\text { [wt.-\%] }\end{array}$ & $\begin{array}{l}\mathrm{Si} \\
\text { [wt.-\%] }\end{array}$ & $\begin{array}{l}P \\
\text { [wt.-\%] }\end{array}$ & $\begin{array}{l}\text { S } \\
\text { [wt.-\%] }\end{array}$ & $\begin{array}{l}\mathrm{Cr} \\
\text { [wt.-\%] }\end{array}$ \\
\hline Armco iron & 0.004 & 0.05 & 0.01 & 0.005 & 0.000 & 0.03 \\
\hline L80 steel & 0.33 & 1.38 & 0.21 & 0.017 & 0.009 & 0.25 \\
\hline
\end{tabular}

Fig. 3: Microstructure of the examined materials: a Armco iron and $\mathbf{b}$ L80 steel
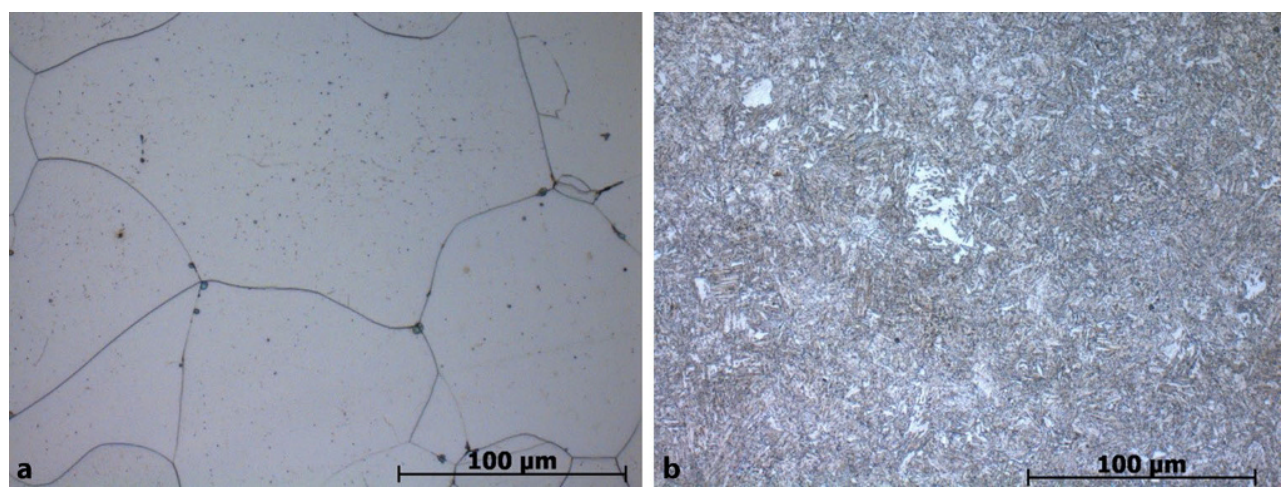

\subsection{Testing Method}

For the immersion testing, the sample was placed in the solution by using a glass sample holder. For longer test periods, the beaker was additionally covered with a watch glass or a sealing film to prevent the solution from evaporating. During the cathodic charging, the sample was placed in the middle of a platinum mesh electrode with a sample holder and the electrolyte was circulated using a magnetic stirrer during the entire test. A power supply unit with a fine adjustment of the current of $1 \mathrm{~mA}$ served as the voltage source. During the charging in a sour gas atmosphere, the samples were placed on the bottom of the

\section{TABLE 2}

Values of the measured Hardness and the estimated

Ultimate Tensile Stress (UTS) of the investigated materials

\begin{tabular}{|llll|}
\hline Material & $\begin{array}{l}\text { Hardness } \\
\text { HV 1 }\end{array}$ & $\begin{array}{l}\text { UTS } \\
{[\mathrm{MPa}]}\end{array}$ & {$[\mathrm{ksi}]$} \\
\hline Armco iron & 80 & 255 & 37 \\
\hline L80 steel & 244 & 780 & 113 \\
\hline
\end{tabular}

respective test containers and subsequently filled with test solution and test gas. The pressurized hydrogen charging was performed by an autoclave testing method. The applied charging methods are shown schematically in Fig. 4.

For all test methods, the following general conditions were applied:

1. Cleaning each sample for $3 \mathrm{~min}$ first in used acetone, then in fresh acetone in an ultrasonic bath;

2. Drying the sample with a paper towel;

3. Test procedure;

4. Immediate cooling in liquid nitrogen after removing the sample from the test container;

5. Wet grinding of the sample with 120 grit abrasive paper without defrosting of the sample;

6. Carrying out the hydrogen analysis by hot carrier gas extraction at $950^{\circ} \mathrm{C}$ (cleaning the sample with acetone-blow-drying-weighing-placing the sample in the hydrogen analyzer).

\begin{tabular}{|c|c|c|c|c|c|}
\hline $\begin{array}{l}\text { Charging } \\
\text { method }\end{array}$ & Medium & $\begin{array}{l}\text { Thiourea } \\
{[\mathrm{g} / \mathrm{l}]}\end{array}$ & $\begin{array}{l}\text { Sour gas } \\
\text { [bar] }\end{array}$ & $\begin{array}{l}\text { Current density } \\
{\left[\mathrm{mA} / \mathrm{cm}^{2}\right]}\end{array}$ & $\begin{array}{l}\text { Hydrogen pressure } \\
\text { [bar] }\end{array}$ \\
\hline Immersion & $3.5 \% \mathrm{NaCl}$ & - & - & - & - \\
\hline Immersion & $1 \mathrm{~m} \mathrm{H}_{2} \mathrm{SO}_{4}$ & - & - & - & - \\
\hline Immersion & $3.5 \% \mathrm{NaCl}$ & 1 & - & - & - \\
\hline Immersion & $1 \mathrm{~m} \mathrm{H}_{2} \mathrm{SO}_{4}$ & 1 & - & - & - \\
\hline Cathodic & $3.5 \% \mathrm{NaCl}$ & 1 & - & 1 & - \\
\hline Cathodic & $1 \mathrm{~m} \mathrm{H}_{2} \mathrm{SO}_{4}$ & 1 & - & 1 & - \\
\hline Hydrogen sulfide & $\mathrm{NaCl} / \mathrm{CH}_{3} \mathrm{COOH}$ & - & 1 & - & - \\
\hline Autoclave & Dry gas & - & - & - & 20 \\
\hline Autoclave & Dry gas & - & - & - & 100 \\
\hline
\end{tabular}


Fig. 4: Schematic representation of the test methods for hy drogen charging: immersion, cathodic charging, hydrogen sulfide charging, autoclave charging

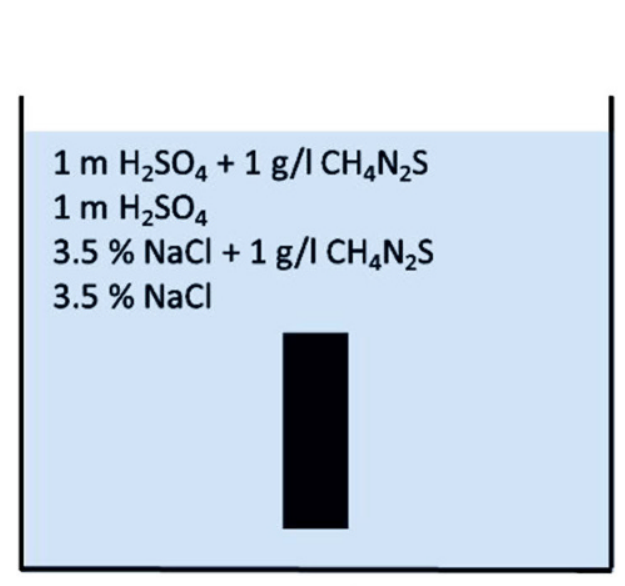

Immersion

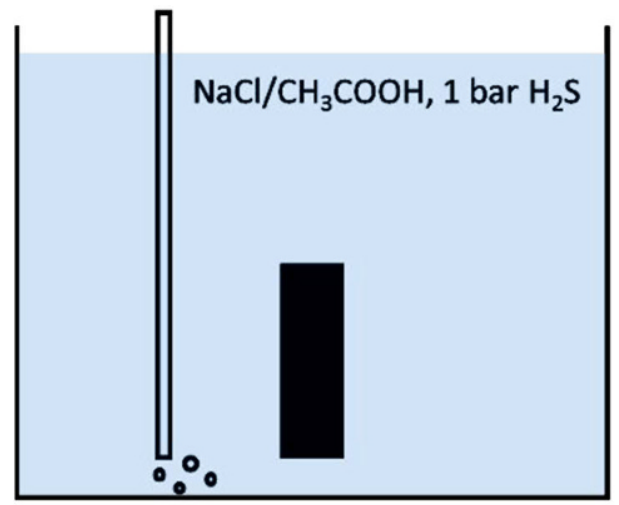

Hydrogen sulfide

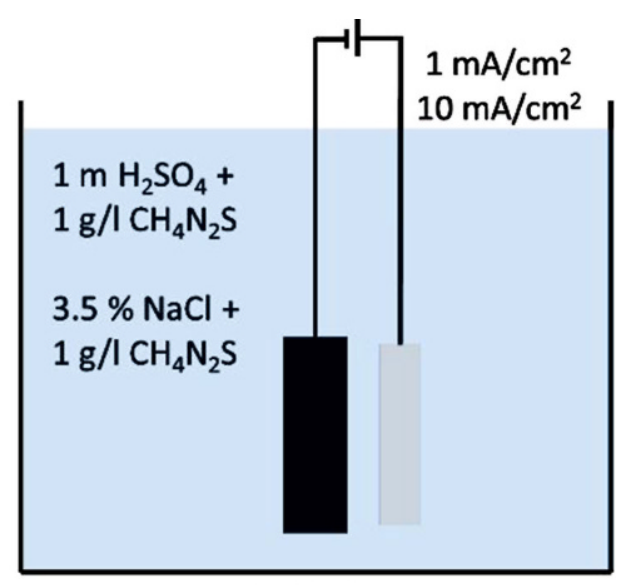

Cathodic

20 bar $\mathrm{H}_{2}$

100 bar $\mathrm{H}_{2}$

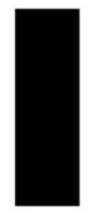

Autoclave

\subsection{Testing Conditions}

All tests were carried out at room temperature for three parallel samples each in the test conditions shown in Table 3.

The charging tests were carried out for between 2 and $336 \mathrm{~h}$. In the case of cathodic hydrogen charging in acidic solution at $20 \mathrm{~h}$, the current density was increased to $10 \mathrm{~mA} / \mathrm{cm}^{2}$. In order to find a correlation between the amount of hydrogen absorbed and the corrosion attack,

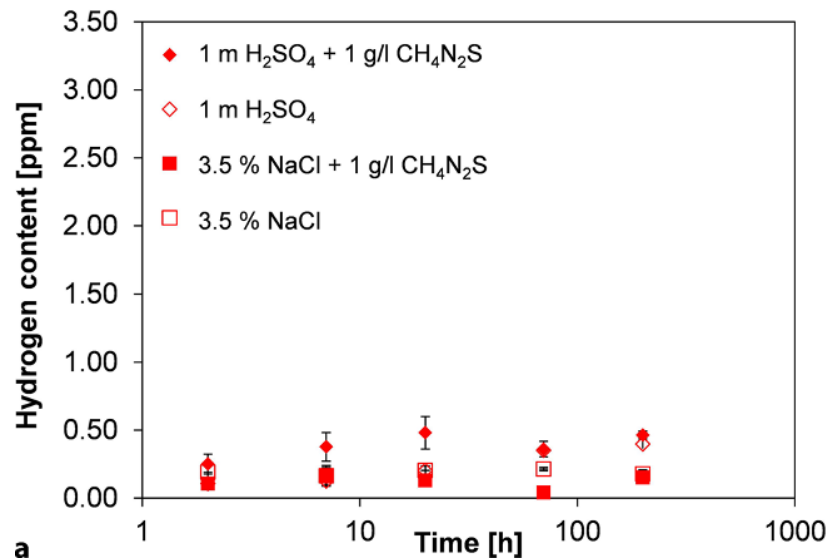

the corrosion rates of some selected experiments were additionally determined gravimetrically and the samples were photo documented.

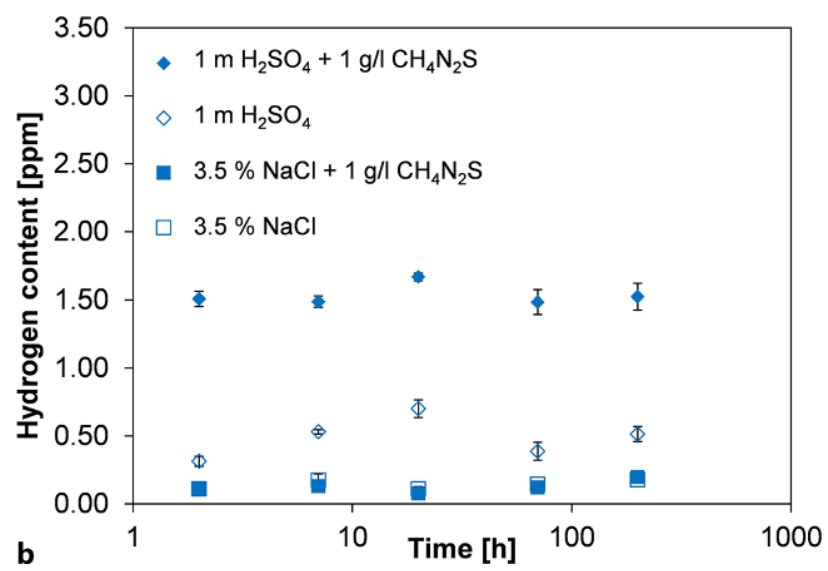

Fig. 5: Hydrogen content during immersion of a Armco iron and b L80 steel at room temperature 

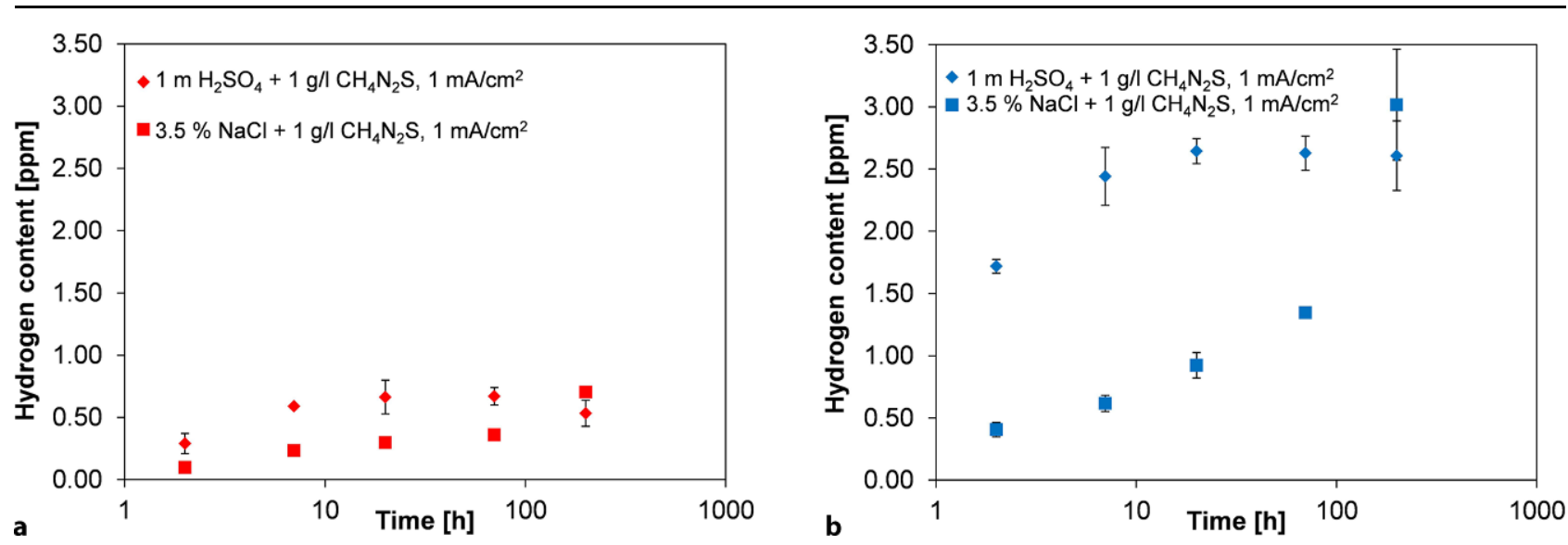

Fig. 6: Hydrogen content during cathodic charging of a Armco iron and $\mathbf{b} L 80$ steel at a current density of $1 \mathrm{~mA} / \mathrm{cm}^{2}$

\section{Results and Discussion}

\subsection{Hydrogen Content}

Before the test was carried out, the hydrogen content of both test materials was determined in the as-delivered condition. The results shown consist of the basic hydrogen content (Armco iron $0.13 \mathrm{ppm}$ and $\mathrm{L} 80$ steel $0.10 \mathrm{ppm}$ ) and the absorbed hydrogen content.

\subsubsection{Immersion}

During the immersion test, the amount of hydrogen absorbed depends primarily on the corrosion attack on the sample and subsequently on the presence of hydrogen poisons. The results of the aging tests can be seen in Fig. 5.

When aging in neutral solutions with an addition of thiourea as a hydrogen poison, the measured values are close to the delivery state, since thiourea shows an inhibiting effect drastically reducing the corrosion attack of the sample. The immersion in the neutral salt solution and in the acidic solution without an inhibitor shows a slightly increased hydrogen absorption due to the corrosion attack. The greatest hydrogen uptake is achieved by charging in the acidic solution with the addition of thiourea, since,

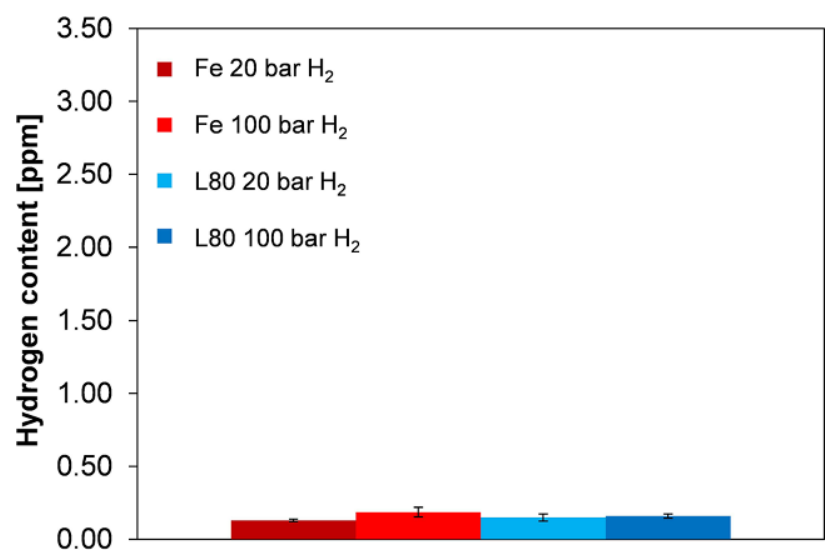

Fig. 7: Hydrogen content during autoclave testing of Armco iron (Fe) and L80 steel (L80) at room temperature despite the inhibiting effect of thiourea, a corrosion attack occurs and thiourea promotes the hydrogen uptake as a result. At a charging time of $20 \mathrm{~h}$, a maximum can be observed due to the formation of a top layer, which is particularly evident in acidic aging. Compared to L80 steel, the hydrogen uptake of Armco iron during immersion is significantly lower, due to a higher corrosion resistance.

\subsubsection{Cathodic Charging}

During the cathodic hydrogen charging, hydrogen can be formed at the cathodically polarized electrode due to the applied potential. Further, depending on the medium, an additional material degradation and the associated formation of hydrogen can occur. It should be noted that the sample is cathodically protected and only a very low corrosion attack takes place in the neutral media. The results of the cathodic hydrogen charging show a clear difference between the neutral and the acidic hydrogen charging methods (Fig. 6).

The neutral hydrogen charging with the addition of thiourea shows a slow increase at higher loading times. The acidic solution, on the other hand, quickly shows a maximum at a loading time of $20 \mathrm{~h}$ and a very slow decrease at longer loading times. The course thus follows the

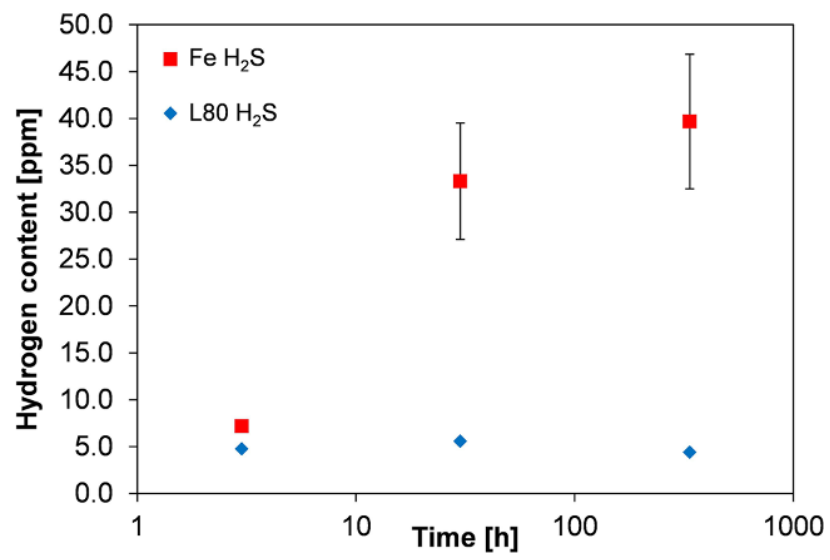

Fig. 8: Hydrogen content during hydrogen sulfide charging according to NACE TM0177 of Armco iron (Fe) and L80 steel (L80) at room temperature 

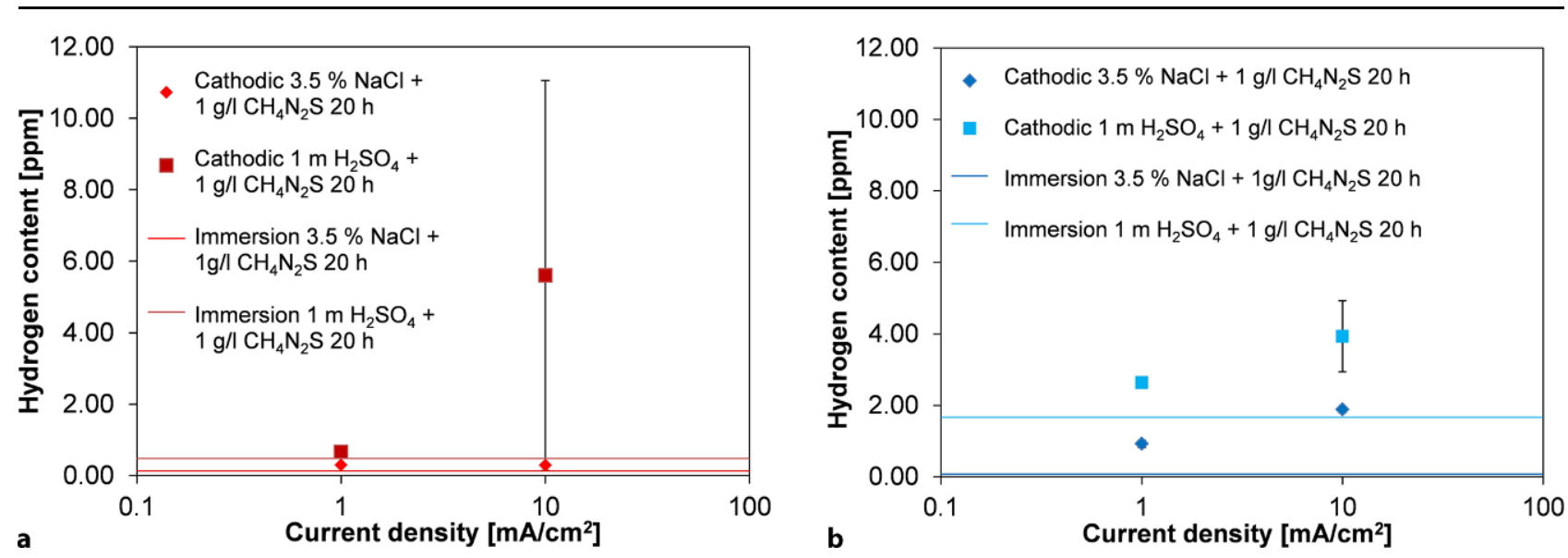

Fig. 9: Hydrogen content of $\mathbf{a}$ Armco iron and $\mathbf{b} \mathrm{L} 80$ steel at room temperature and varying current densities

Fig. 10: Gravimetrically determined mass loss of the samples after hydrogen charging in various conditions

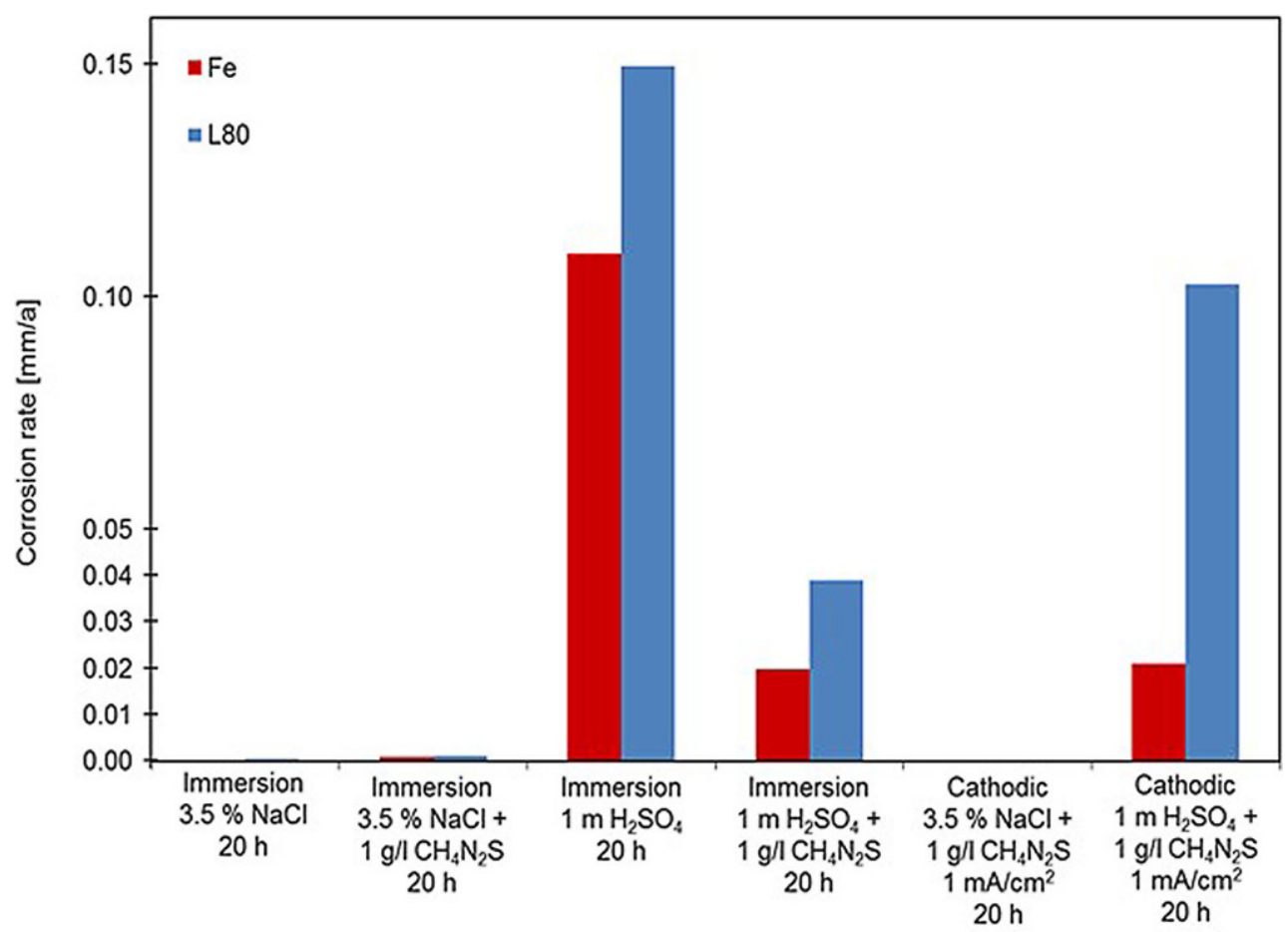

observations of the charging in an acidic immersion test without applied voltage and can also be traced back to the formation of a top layer. The values for L80 steel are again significantly higher than those for Armco iron.

\subsubsection{Autoclave Charging}

The hydrogen charging in a pressurized hydrogen atmosphere did not lead to a significant hydrogen absorption either in Armco iron or L80 steel (Fig. 7).

\subsubsection{Hydrogen Sulfide Charging}

For the hydrogen charging under a sour gas atmosphere, the mean values and standard deviations were determined from two values. In the experiments after 30 and $336 \mathrm{~h}$, Armco iron showed a clear bubble formation, which was audible and visually perceptible during the grinding of the samples. In addition, Armco iron only showed an optically visible surface layer after a charging time of $336 \mathrm{~h}$, which explains the high hydrogen content and the slow reaching of a plateau (Fig. 8). L80 steel, however, already showed a layer formation after short loading times and there was no blistering during the whole experiment.

\subsubsection{Current Density}

The influence of the current density is shown in Fig. 9. In the case of Armco iron, two out of three samples with a charging current density of $10 \mathrm{~mA} / \mathrm{cm}^{2}$ in the acidic solution showed blistering and thus an enormous drift of the hydrogen content. When considering the absorption by L80 steel at higher charging current densities, there is also a significantly higher dispersion of the values in the acidic 
solution and a general increase in the hydrogen content at higher current densities. For L80 steel, the increase in the amount of hydrogen absorbed is significantly lower compared to Armco iron. Therefore it can be concluded that L80 steel forms a denser top layer than Armco iron under aggressive conditions and thus counteracts the absorption of hydrogen more strongly.

\subsubsection{Mass Loss}

In order to confirm the results from the charging tests, six samples of each material were charged for $20 \mathrm{~h}$ and optically inspected. Then the corrosion rate was determined gravimetrically (Fig. 10).

When determining the corrosion rate, the inhibiting influence of the thiourea can be proven, since a significantly higher mass loss was recognizable in the acidic solution during the ageing of both materials than in the solution inhibited with thiourea. In the case of cathodic charging, on the other hand, no corrosive attack occurs in the neutral solution; however, in the case of the acidic solution, especially for L80 steel, there is an increased corrosive attack and consequently a charging caused by this and by the current. This also explains the rapid occurrence of a maximum amount of hydrogen in the acidic cathodic charging.

\section{Conclusions}

During the immersion in neutral solutions, in particular due to an inhibiting effect caused by the addition of thiourea, there is no significant hydrogen uptake in both materials. L80 steel absorbs more hydrogen than Armco iron due to a larger number of traps and a higher corrosion rate during immersion in acidic solutions and during electrochemical charging. Only by applying higher current densities or $\mathrm{H}_{2} \mathrm{~S}$ tests, higher hydrogen concentrations occur in Armco iron due to blistering and a lack of layer formation.

Funding. Open access funding provided by Montanuniversität Leoben.

Open Access This article is licensed under a Creative Commons Attribution 4.0 International License, which permits use, sharing, adaptation, distribution and reproduction in any medium or format, as long as you give appropriate credit to the original author(s) and the source, provide a link to the Creative Commons licence, and indicate if changes were made.
The images or other third party material in this article are included in the article's Creative Commons licence, unless indicated otherwise in a credit line to the material. If material is not included in the article's Creative Commons licence and your intended use is not permitted by statutory regulation or exceeds the permitted use, you will need to obtain permission directly from the copyright holder. To view a copy of this licence, visit http://creativecommons.org/licenses/by/4.0/.

\section{References}

1. Johnson, W. H.: On some remarkable changes produced in iron and steel by the action of hydrogen and acids, Proceedings of the Royal Society of London, 23 (1874), pp 168-179

2. Rehrl, J.: Wasserstoffversprödung in hochfesten, mikrolegierten Stählen, Dissertation, TU München, 2013

3. Pillot, S.; Coudreuse, L.: Hydrogen-induced disbonding and embrittlement of steels used in petrochemical refining, in: Gangloff, R. P.; Somerday, B. P. (Eds.): Gaseous hydrogen embrittlement of materials in energy technologies, Cambridge: Woodhead Publishing, 2012, pp 51-93

4. Li, Y.; H. Wang, H.; Xie, L.; Liang, Y.; Hong, G.; Dai, H.: MoS 2 nanoparticles grown on graphene: an advanced catalyst for the hydrogen evolution reaction, Journal of the American Chemical Society, 133 (2011), pp 7296-7299

5. Takagi, S.; Toji, Y.: Application of $\mathrm{NH}_{4} \mathrm{SCN}$ Aqueous Solution to Hydrogen Embrittlement Resistance Evaluation of Ultra-high Strength Steels, ISIJ International, 52 (2012), pp 329-331

6. Cheng, Y. F.; Niu, L.: Mechanism for hydrogen evolution reaction on pipeline steel in near-neutral $\mathrm{pH}$ solution, Electrochemistry Communications, 9 (2007), pp 558-562

7. Hieber, H.; Erdmann-Jesnitzer, F.: Das Verhalten von kohlenstoffarmem Stahl bei Wasserstoffbeladung und plastischer Verformung, Archiv Eisenhüttenwesen, 44 (1973), pp 685-690

8. Mertens, G.; Duprez, L.; de Cooman, B. C.; Verhaege, M.: Hydrogen Absorption and Desorption in Steel by Electrolytic Charging, Advanced Materials Research, 15 (2006), pp 816-821

9. Pérez Escobar, D.; Miñambres, C.; Duprez, L.; Verbeken, K.; Verhaege, M.: Internal and surface damage of multiphase steels and pure iron after electrochemical hydrogen charging, Corrosion Science, 53 (2011), pp 3166-3176

10. Lei, X.; Wang, H.; Mao, F.; Zhang, J.; Zhao, M.; Fu, A.; Feng, Y.; Macdonald, D. D.: Electrochemical behaviour of martensitic stainless steel after immersion in a $\mathrm{H}_{2} \mathrm{~S}$-saturated solution, Corrosion Science, 131 (2018), pp164-173

11. Kaesche, H.: Die Korrosion der Metalle: Physikalisch-chemische Prinzipien und aktuelle Probleme, Springer-Verlag, Berlin, et al., 2012

12. Tiwari, G. P.; Bose, A.; Chakravartty, J. K.; Wadekar, S. L.; Totlani, M. K.; Arya, R. N.; Fotedar, R. K.: A Study of internal Hydrogen Embrittlement of Steels, Materials Science and Engineering A, 286 (2000), pp 269-281

Publisher's Note. Springer Nature remains neutral with regard to jurisdictional claims in published maps and institutional affiliations. 